\title{
Tufted angioma
}

INSERM

\section{Source}

INSERM. (1999). Orphanet: an online rare disease and orphan drug data base. $\underline{\text { Tufted }}$ angioma. ORPHA:1063

Tufted angioma is a very rare, benign, cutaneous, slow-growing, vascular tumor mostly developing in infancy or early childhood. 